\title{
IMPAIRMENT BY BACTEROIDES SPECIES OF OPSONISATION AND PHAGOCYTOSIS OF ENTEROBACTERIA
}

\author{
G. R. Jones And C. G. Gemmell \\ Department of Bacteriology, Medical School, \\ University of Glasgow Royal Infirmary, Glasgow G4 OSF
}

\begin{abstract}
Summary. The ability of human polymorphonuclear leucocytes to phagocytose and kill Proteus mirabilis was impaired in vitro when the human serum, used to opsonise the target bacteria, was pretreated with cultures of various Bacteroides species. Live and dead, either heatkilled or clindamycin-treated, bacteroides cells elicited the same phenomenon. When bacteroides-treated serum was used to opsonise different Proteus species, the subsequent uptake of all strains by polymorphonuclear leucocytes was inhibited, whereas bacteroides-treated serum inhibited the uptake of some but not all of the test strains of Escherichia coli. The opsonic activity of untreated human serum was reduced when the classical complement pathway was inhibited by ethyleneglycolbis-( $\beta$-aminoethyl ether) $\mathrm{N}, \mathrm{N}^{\prime}$-tetra-acetic acid (EGTA); subsequent treatment with bacteroides did not further reduce the opsonic activity of the serum for $P$. mirabilis.
\end{abstract}

\section{INTRODUCTION}

The susceptibility of pathogenic micro-organisms to phagocytosis by polymorphonuclear leucocytes (PMNL) and macrophages is important in determining the outcome of the host-parasite relationship. Interference with normal phagocytic processes by bacterial products can often determine the severity and extent of infection. Individual bacteria can elaborate substances that interfere with phagocytosis (for review see Quie, Giebink and Peterson, 1981).

However, the effect of cells of one bacterial species on the phagocytosis of another was not studied experimentally until Ingham et al. (1977) reported that some Bacteroides species are capable of inhibiting the phagocytic killing of various bacteria by human PMNL in vitro. This inhibition depended on a low $E$ h and required at least $10^{7}$ anaerobes $/ \mathrm{ml}$ in the phagocytic system. Facultative anaerobes such as Escherichia coli did not impair phagocytosis of Proteus mirabilis.

Tofte et al. (1980) found that the uptake of $E$. coli by PMNL was markedly inhibited in the presence of Bacteroides fragilis or B. melaninogenicus, but conversely $E$. coli did not significantly affect the uptake of either anaerobe. These workers suggested 
that the test bacteroides were either more efficiently or more rapidly opsonised than $E$. coli and therefore deprived $E$. coli of serum opsonins needed for efficient phagocytosis by PMNL.

The present study was undertaken to determine the extent of the inhibition of phagocytosis by bacteroides. Some of the factors involved were investigated by measuring the uptake of radiolabelled bacteria and the killing of P. mirabilis and E. coli by PMNL in the presence or absence of bacteroides organisms.

\section{MATERIALS AND METHODS}

Bacterial strains. B. melaninogenicus strain no. 4 and Proteus mirabilis strain NGH were kindly provided by Dr H.R. Ingham, General Hospital, Newcastle upon Tyne, NE4 6BE. Twelve strains of bacteroides and 28 enterobacteria were randomly chosen from fresh clinical isolates obtained in the Bacteriology Department, Royal Infirmary, Glasgow G4 0SF. Identification of the Bacteroides species was based on the method of Duerden et al. (1980), and of the coliforms by the API 20E system (API Laboratory Products, Grafton Way, Basingstoke, Hants RG22 6HY.

The species included in this study were $E$. coli (14 strains), $P$. vulgaris ( 3 strains), $P$. mirabilis (7 strains), $P$. morgani (4 strains), B. melaninogenicus (6 strains), B. fragilis (5 strains) and $B$. thetaiotaomicron and B. vulgatus (1 strain each).

Culture of bacteroides. Each isolate was cultured in a medium consisting of Cooked Meat Particles (Difco) reconstituted in Brain Heart Infusion Broth (Difco) to which menadione (1 $\mu \mathrm{g} / \mathrm{ml}$, Sigma Chemical Company, St Louis) and haemin $(5 \mu \mathrm{g} / \mathrm{ml}$, Sigma) were added. Cultures were incubated for $48 \mathrm{~h}$ at $37^{\circ} \mathrm{C}$ and used in the experiments without subsequent treatment unless otherwise stated.

Culture and radiolabelling of the enterobacteria. The Proteus and E. coli isolates were cultured overnight in $20 \mathrm{ml}$ of Mueller-Hinton Broth (Oxoid) containing ${ }^{3} \mathrm{H}$-thymidine (specific activity $25 \mathrm{Ci} / \mathrm{mmol}$; Radiochemical Centre, Amersham, Bucks HP7 9LL) at a final concentration of $10 \mu \mathrm{Ci} / \mathrm{ml}$ broth. After incubation, the bacteria were centrifuged at $3000 \mathrm{~g}$ for $10 \mathrm{~min}$ and washed three times with $0.85 \%$ saline before use.

Opsonisation. Fresh human serum obtained from the Haematology Department, Glasgow Royal Infirmary, was divided into $5-\mathrm{ml}$ portions and stored at $-70^{\circ} \mathrm{C}$ before use. For opsonisation, serum was diluted to $50 \%$ with Hanks's balanced salt solution containing $0 \cdot 1 \%$ gelatin (gel-HBSS). The washed radiolabelled test bacterial suspension was diluted with saline to contain approximately $5 \times 10^{7}$ organisms $/ \mathrm{ml}$ by spectrophotometric determination. Equal volumes of the standardised bacterial suspension and $50 \%$ serum in gel-HBSS were mixed, incubated at $37^{\circ} \mathrm{C}$ for $15 \mathrm{~min}$ in an orbital incubator (shaking speed $150 \mathrm{rpm}$ ) and then centrifuged at $3000 \mathrm{~g}$ for $10 \mathrm{~min}$. The bacterial pellet was resuspended in gel-HBSS to its original volume.

In some experiments the human serum was heat treated at $56^{\circ} \mathrm{C}$ for 30 min to inactivate complement before opsonisation. The heated serum failed to opsonise E. coli or Proteus organisms and this was assumed to indicate that little or no antibody with opsonic activity remained. Serum complement activation via the classical pathway was inhibited by addition of $0.1 \mathrm{ml}$ of $0.1 \mathrm{M}$ ethyleneglycol-bis-( $\beta$-aminoethyl-ether) $\mathrm{N}, \mathrm{N}^{1}$-tetra-acetic acid (EGTA, Sigma) to $0.9 \mathrm{ml}$ serum and held at room temperature for $30 \mathrm{~min}$. Further dilutions of the chelated serum were then made in $0.85 \%$ saline.

Leucocyte preparation. Venous blood was obtained from individual healthy volunteers; it was heparinised (10 U heparin/ml blood) and mixed with dextran (mol. wt $150000 ; 6 \% \mathrm{w} / \mathrm{v}$ in $0.85 \%$ saline; Fisons Limited, Loughborough, Leics LE11 ORG) in a blood:dextran solution ratio of $4: 1$. Sedimentation of erythrocytes was allowed for $20-30 \mathrm{~min}$. The supernatant fluid and the cells at the interface were removed and centrifuged at $100 \mathrm{~g}$ for $5 \mathrm{~min}$. The deposit was suspended in $0.87 \%$ ammonium chloride (BDH Chemicals Ltd, Poole, Dorset BH12 4NN) and mixed gently for 15-20 min to allow lysis of the erythrocytes. After centrifugation at $100 \mathrm{~g}$ for 5 min, the leucocytes were suspended in gel-HBSS and adjusted to contain approximately $5 \times 10^{6}$ $\mathrm{PMNL} / \mathrm{ml}$ as determined with a haemocytometer. 
Uptake of radiolabelled bacteria. The method of Verhoef, Peterson and Quie (1977) was followed. For each phagocytosis mixture, duplicate test vials containing $0.1 \mathrm{ml}$ of radiolabelled, opsonised bacteria and $0.1 \mathrm{ml}$ of the leucocyte suspension were incubated for $45 \mathrm{~min}$ at $37^{\circ} \mathrm{C}$ in an orbital incubator (shaking speed $150 \mathrm{rpm}$ ). Duplicate controls containing gel-HBSS in place of the leucocyte suspension were included. After incubation, $3 \mathrm{ml}$ of scintillation fluid (Aqualuma, Lumac Systems AG, Basle) was added to one of the test and to one of the control vials. Measurement of radioactivity in these vials provided an estimate of the total number of bacteria present in each phagocytic mixture. To the other test and control vial, $3 \mathrm{ml}$ of ice-cold

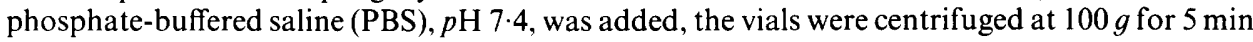
to sediment the PMNL and the supernatant fluid was discarded. These vials were given two more washes with PBS and $3 \mathrm{ml}$ of scintillation fluid was then added to each vial. Measurement of radioactivity in these vials provided an estimate of the number of ingested bacteria present in each phagocytic mixture. The counts per minute of the contents of each vial were determined in a liquid scintillation counter (1210 Ultrobeta, LKB Instruments, 232 Addington Way, S. Croydon, Surrey CR2 8YD). The percentage uptake of labelled bacteria was calculated as follows:

$$
\frac{\mathrm{cpm} \text { : centrifuged mixture containing PMNL }}{\mathrm{cpm} \text { : uncentrifuged mixture containing PMNL }} \times 100 \text {. }
$$

This value was corrected by subtracting the corresponding value obtained from the counts recorded for the vials that did not contain PMNL.

Measurement of phagocytosis. Phagocytosis and killing of bacteria by leucocytes was estimated by the method of Ingham et al. (1977). Briefly, $0.5 \mathrm{ml}$ of leucocyte suspension, $0 \cdot 1 \mathrm{ml}$ of serum (undiluted), $0 \cdot 1 \mathrm{ml}$ of coliform suspension, $0 \cdot 1 \mathrm{ml}$ of bacteroides suspension (containing $10^{8}-10^{9}$ organisms $/ \mathrm{ml}$ of Robertson's cooked meat medium) and $0.2 \mathrm{ml}$ of gel-HBSS were incubated aerobically at $37^{\circ} \mathrm{C}$ for up to $5 \mathrm{~h}$ in an orbital incubator. Controls without serum, leucocytes or bacteroides culture were included, with gel-HBSS substituted in each case. After incubation, tenfold dilutions of the mixtures were made in distilled water and 20- $\mu$ lamounts of each dilution were inoculated onto agar plates in duplicate. Gentamicin blood-agar plates, containing gentamicin $50 \mu \mathrm{g} / \mathrm{ml}$, to inhibit the growth of Proteus and E. coll, were used for the anaerobes, and cystine lactose electrolyte-deficient medium (CLED, CM 301 Oxoid) was used for the coliforms. After incubation, the viable count was calculated according to the method of Miles, Misra and Irwin (1938).

Statistical analysis of the results was performed by the Mann-Whitney $\mathrm{U}$ test.

\section{RESULTS}

\section{Factors affecting uptake of labelled bacteria}

The mean uptake of radiolabelled opsonised cells of $P$. mirabilis strain NGH by PMNL was $81 \%$ compared with $3 \%$ for unopsonised $P$. mirabilis cells (fig. 1). The uptake of this strain was markedly reduced $(\mathrm{p}<0.001)$ when the bacteria were opsonised with serum pretreated with $B$. melaninogenicus strain 4 , and less markedly but still significantly reduced when opsonised with untreated serum in the presence of $B$. melaninogenicus cells.

In tests with several different isolates of Proteus and E. coli (see fig. 2), pretreatment of the serum with $B$. melaninogenicus strain 4 significantly inhibited $(p<0.001)$ the uptake of most (10/14) of the Proteus isolates. The uptake of E. coli isolates was more varied; the uptake of seven of the 14 isolates was inhibited by more than $50 \%$ but with five isolates there was little or no change in uptake.

Pretreatment of the serum with any of the 13 isolates of Bacteroides inhibited the uptake of $P$. mirabilis strain NGH by at least $50 \%$ (table I). When E. coli was substituted for Bacteroides there was little change in the uptake of the proteus by 


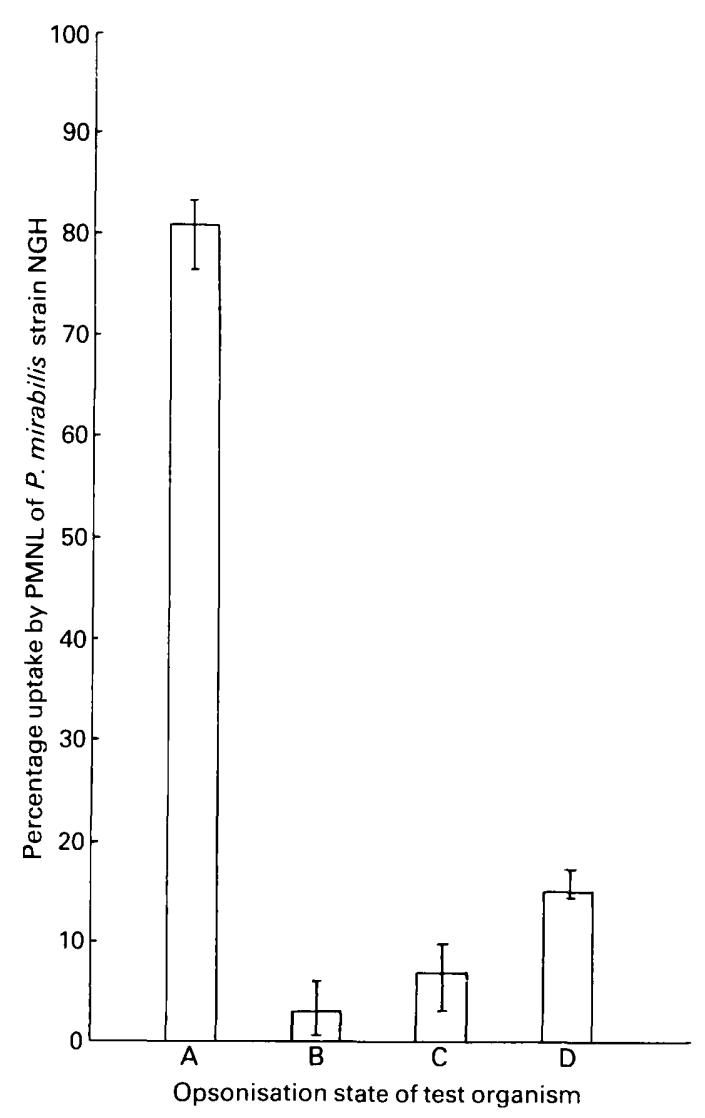

FIG. 1-Effect of $B$. melaninogenicus strain 4 on the uptake of $P$. mirabilis strain NGH by polymorphonuclear leucocytes (PMNL). $\mathrm{A}=$ opsonised; $\mathrm{B}=$ non-opsonised; $\mathrm{C}=$ opsonised with serum treated with $B$. melaninogenicus strain $4 ; \mathrm{D}=$ opsonised in presence of $B$. melaninogenicus strain 4 . Each result represents the mean and range of at least three experiments.

PMNL. Similarly, if serum treated with $E$. coli was used for opsonisation or if pre-opsonised $P$. mirabilis strain NGH cells were incubated with $E$. coli, there was no alteration in the uptake of the radio-labelled bacteria by PMNL ( $>>0.005$ ) (fig. 3). When simultaneous opsonisation of $P$. mirabilis strain NGH and $E$. coli was carried out, the mean uptake of the proteus was reduced from $80 \%$ to $60 \%$ but this difference was not statistically significant $(\mathrm{p}>0.05)$.

When culture filtrates of $B$. melaninogenicus strain 4 were incubated with normal human serum before opsonisation of $P$. mirabilis strain $\mathrm{NGH}$, the uptake of $P$. mirabilis NGH was significantly reduced $(\mathrm{p}<0.001)$ indicating that a cell-free component in the culture supernate might be involved (fig. 4). Similarly, a heat-killed $B$. melaninogenicus culture and a suspension of $B$. melaninogenicus strain 4 in saline containing $1 \%$ ascorbic acid impaired the uptake of $P$. mirabilis strain $\mathrm{NGH}$ $(p<0 \cdot 001)$. To exclude the possibility that the bacteria per se might be causing a direct effect on the PMNL, PMNL were preincubated with either unopsonised B. melaninogenicus strain 4, P. mirabilis strain NGH or E. coli, and these PMNL showed normal uptake of opsonised P. mirabilis (table II). 


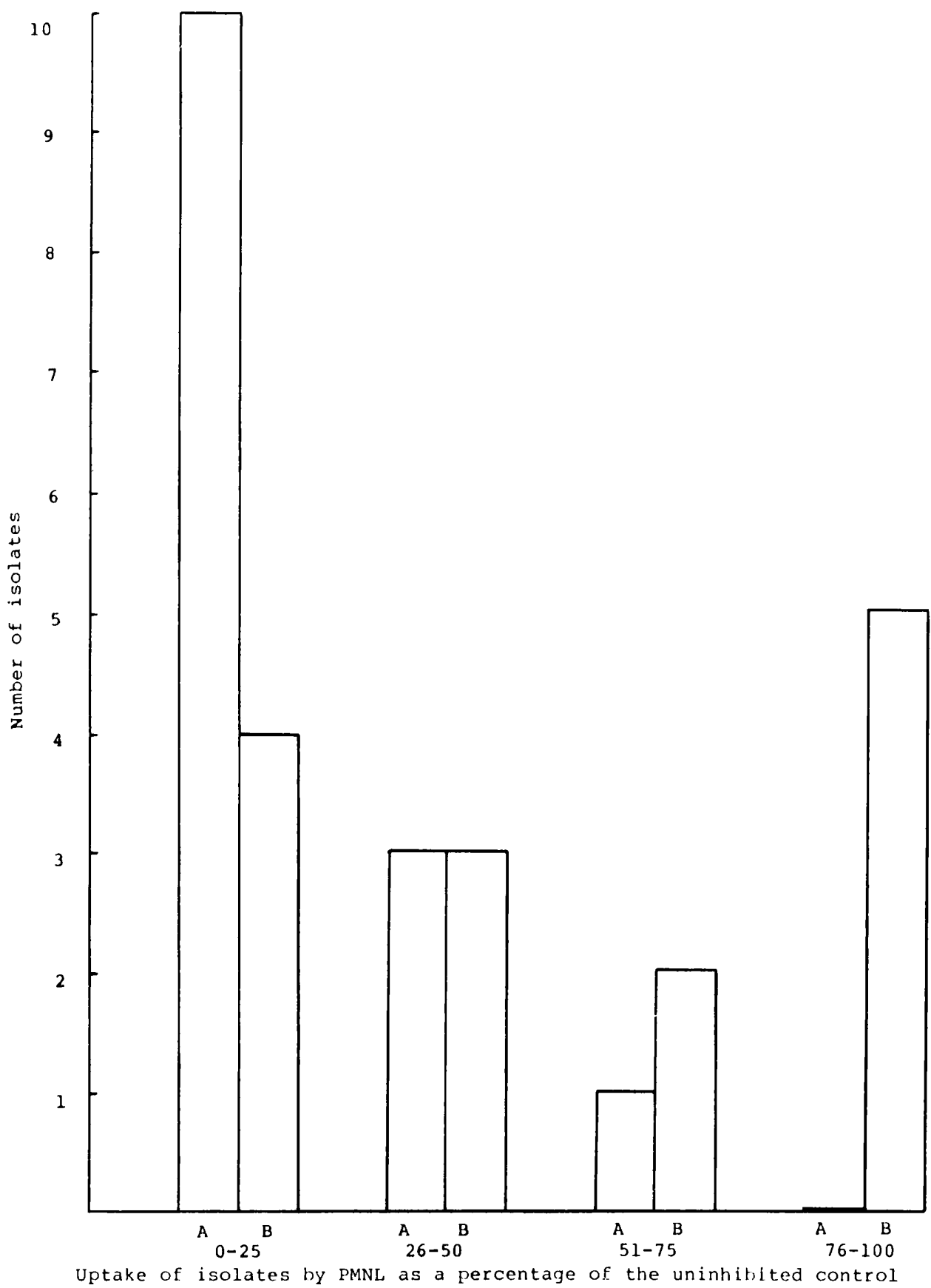

F1G. 2-Frequency of uptake by polymorphonuclear leucocytes (PMNL) of various isolates of Proteus (7 strains of $P$. mirabilis, 3 of $P$. vulgaris, 4 of $P$. morgani) and 14 isolates of $E$. coli opsonised with serum pretreated with $B$. melaninogenicus strain 4 . Values are expressed as a percentage of the corresponding uptake of each isolate opsonised with normal human serum. $\mathrm{A}=$ Proteus; $\mathrm{B}=E$. coli. 
TABLE I

Phagocytic uptake by PMNL of Proteus mirabilis strain NGH opsonised with serum treated with various bacteroides isolates

\begin{tabular}{|c|c|}
\hline $\begin{array}{l}\text { Species and strain no. } \\
\text { of organism used for } \\
\text { pretreatment of serum }\end{array}$ & $\begin{array}{l}\text { Percentage uptake of } \\
\text { P. mirabilis strain NGH } \\
\text { by PMNL* }\end{array}$ \\
\hline B. melaninogenicus & $\begin{array}{l}15 \\
14 \\
14 \\
17 \\
18 \\
21\end{array}$ \\
\hline B. fragilis & $\begin{array}{l}23 \\
31 \\
29 \\
30 \\
26\end{array}$ \\
\hline B. thetaiotaomicron & 15 \\
\hline B. vulgatus & 31 \\
\hline
\end{tabular}

* Normal serum opsonisation allowed $75 \%-100 \%$ uptake by polymorphonuclear leucocytes (PMNL).

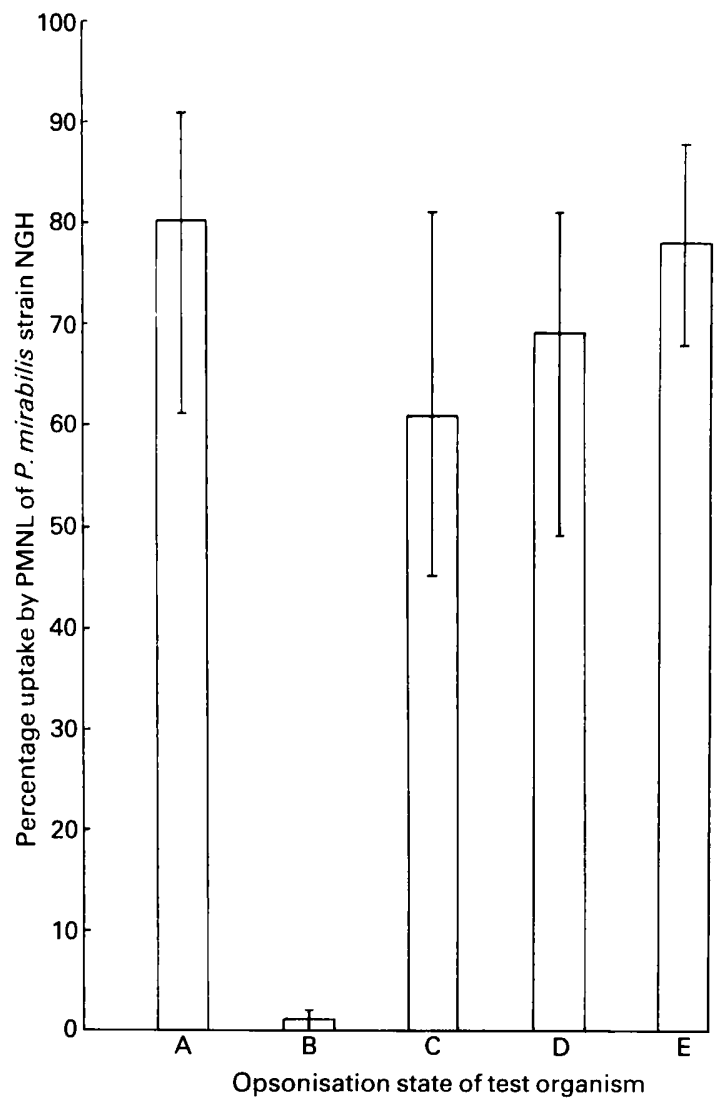

FIG. 3-Effect of $E$. coli on the uptake of $P$. mirabilis strain NGH by polymorphonuclear leucocytes $(\mathrm{PMNL}) . \mathrm{A}=$ opsonised; $\mathrm{B}=$ non-opsonised; $\mathrm{C}=$ opsonised in presence of $E$. coli; $\mathrm{D}=$ opsonised with serum previously treated with $E$. coli; $\mathrm{E}=$ opsonised and subsequently incubated with $E$. coli. Each result represents the mean and range of at least three experiments. 


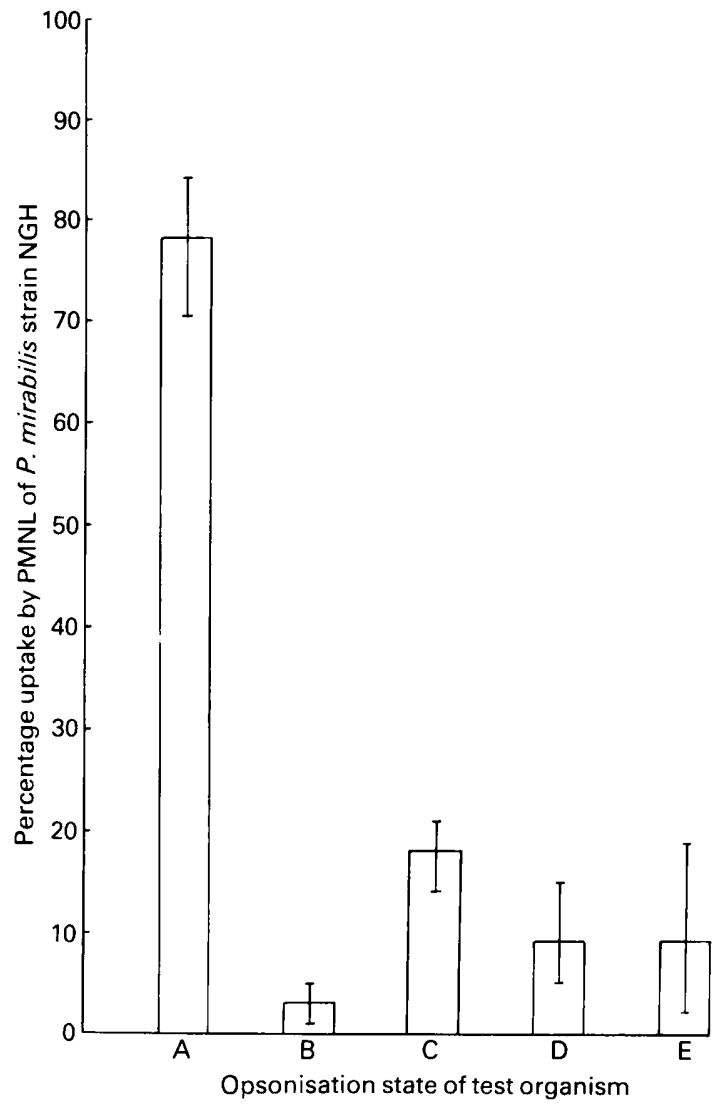

FIG. 4 -Effect of heat-killed $B$. melaninogenicus strain $4, B$. melaninogenicus strain 4 culture filtrate, and a suspension of $B$. melaninogenicus strain 4 in saline containing $1 \%$ ascorbic acid on the uptake by PMNL of $P$. mirabilis strain NGH opsonised with serum treated with these preparations. $\mathrm{A}=$ opsonised; $\mathrm{B}=$ opsonised with serum treated with $B$. melaninogenicus strain 4 culture; $\mathrm{C}=$ opsonised with serum treated with $B$. melaninogenicus strain 4 culture filtrate; $D=$ opsonised with a heat-killed culture of $B$. melaninogenicus strain $4 ; E=$ opsonised with serum treated with $B$. melaninogenicus strain 4 suspended in saline containing $1 \%$ ascorbic acid. Each result represents the mean and range of at least three experiments.

When serum treated with EGTA to inhibit the classical complement pathway was used to opsonise $P$. mirabilis strain NGH, the mean uptake of bacteria was reduced from $88 \%$ to $30 \%$ (fig. 5). Treatment of EGTA-treated serum with B. melaninogenicus strain 4 before the opsonisation of $P$. mirabilis strain NGH resulted in a mean uptake of $19 \%$ by PMNL. This is comparable with a $24 \%$ uptake when normal serum pretreated with $B$. melaninogenicus strain 4 was used for opsonisation.

\section{Effect of B. melaninogenicus on phagocytic killing}

In these studies the assay system of Ingham et al. (1977) was used to measure the efficiency of bacterial killing by PMNL in the presence or absence of other bacteria. The susceptibility of $P$. mirabilis strain NGH was measured over a 5 -h period at $37^{\circ} \mathrm{C}$. Viable counts taken at this time showed that $P$. mirabilis strain NGH was markedly 
TABLE II

Effect of pre-incubation of PMNL with different non-opsonised organisms on uptake of opsonised P. mirabilis

\begin{tabular}{l|c}
\hline PMNL pre-incubated with & $\begin{array}{c}\text { Percentage uptake of } \\
\text { opsonised } P \text {. mirabilis }\end{array}$ \\
\hline buffered saline control & 92 \\
B. melaninogenicus strain 4 & 90 \\
E. coli & 87 \\
P. mirabilis strain NGH & 86 \\
\hline
\end{tabular}

protected from phagocytic killing when $B$. melaninogenicus strain 4 was present in the reaction mixture (table III) and the inhibitory index of phagocytosis (Ingham et al. 1977) was $4.7 \times 10^{3}$. After incubation of PMNL and $P$. mirabilis strain NGH for $1 \mathrm{~h}$ there was a 60 -fold loss of bacterial viability whereas only a 30 -fold loss of viability

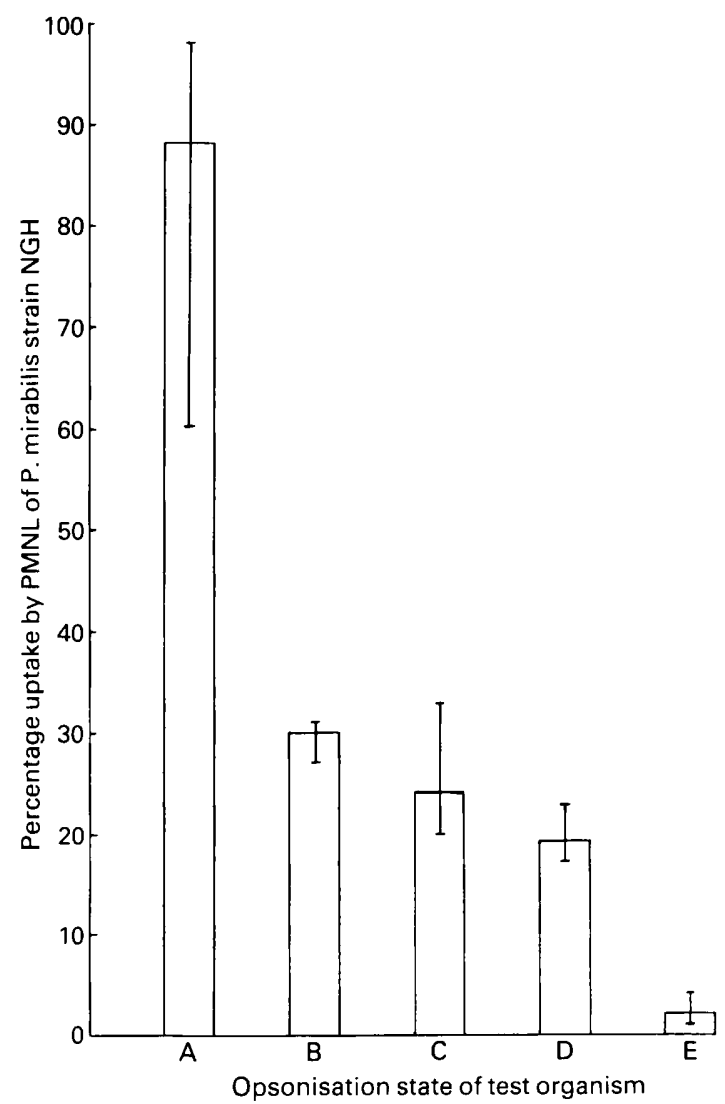

FIG. 5-Effect of B. melaninogenicus 4 on the uptake by PMNL of $P$. mirabilis strain NGH opsonised with untreated or EGTA-treated serum. A=opsonised with untreated serum; $B=$ opsonised with EGTA-treated serum; $C=$ opsonised with serum treated with $B$. melaninogenicus strain $4 ; D=o p-$ sonised with EGTA treated serum followed by treatment with $B$. melaninogenicus strain 4 ; $\mathrm{E}=$ non-opsonised. Each result represents the mean and range of at least three experiments. 
TABLE III

Effect of B. melaninogenicus strain 4 on phagocytosis and killing of P. mirabilis strain NGH and E. coli

\begin{tabular}{|c|c|c|c|}
\hline \multirow[b]{2}{*}{ Organism } & \multicolumn{2}{|c|}{ Viable count at $5 h^{*}$ with } & \multirow{2}{*}{$\begin{array}{c}\text { Inhibitory } \\
\text { index } \dagger\end{array}$} \\
\hline & $\begin{array}{l}\text { B. melaninogenicus } \\
\text { present absent }\end{array}$ & $\begin{array}{c}\text { control } \\
\text { (No PMNL) }\end{array}$ & \\
\hline $\begin{array}{l}\text { P. mirabilis strain } \mathrm{NGH} \\
\text { E. coli }\end{array}$ & $\begin{array}{ll}7.0 \times 10^{8} & 1.5 \times 10^{5} \\
3.5 \times 10^{6} & 6.5 \times 10^{4}\end{array}$ & $\begin{array}{l}1.0 \times 10^{9} \\
1.0 \times 10^{9}\end{array}$ & $\begin{array}{l}4.7 \times 10^{3} \\
5 \cdot 4 \times 10^{1}\end{array}$ \\
\hline
\end{tabular}

* Mean of at least three experiments

+ Inhibitory index is the ratio of the viable count at $5 \mathrm{~h}$ of $E$. coli or P. mirabilis in the presence of $B$. melaninogenicus to that obtained in the absence of proteus organisms.

occurred when $B$. melaninogenicus strain 4 was present. In contrast $E$. coli caused less inhibition of phagocytosis (inhibitory index: 54); most of the added bacteria were phagocytosed and killed. The number of viable $B$. melaninogenicus strain 4 remained virtually constant $\left(5 \times 10^{7}\right.$ bacteria $/ \mathrm{ml}$ of phagocytosis mixture $)$ throughout. Neither killing $B$. melaninogenicus strain 4 by heat $\left(100^{\circ} \mathrm{C}\right.$ for $\left.10 \mathrm{~min}\right)$ nor clindamycin $(50$ $\mu \mathrm{g} / \mathrm{ml}$ culture) affected its ability to impair phagocytosis of $P$. mirabilis by PMNL.

\section{Discussion}

These results confirm and extend the findings of Ingham et al. (1977) who reported the inhibition of phagocytic killing of various bacteria by Bacteroides species. The inhibition probably results solely from impairment of the phagocytic ingestion of bacteria.

The phagocytic uptake of all the Proteus strains tested was markedly impaired in contrast to that of some of the $E$. coli strains. The latter could be divided into those whose uptake by PMNL was inhibited by more than $50 \%$ or by less than $50 \%$ by Bacteroides. This variation may be due to differences in surface structures. Tofte $e t$ al. (1980) investigated only one strain of $E$. coli and found that its uptake by PMNL was inhibited by $B$. melaninogenicus and by $B$. fragilis.

Ingham et al. (1977) suggested that complement was unlikely to be the sole serum component affected by bacteroides treatment of serum. The present studies support the theory of Tofte et al. (1980) that competition for serum opsonins is the basis for the observed impairment of phagocytosis. Chelation of serum with EGTA to inhibit the classical pathway of complement reduced the uptake of $P$. mirabilis by PMNL but did not alter the reduced uptake that followed opsonisation with bacteroides-treated serum. Thus it appears that the bacteroides cells do not owe their activity to the impairment of the alternative complement pathway but to an action on the classical pathway. Preliminary experiments suggest that levels of $\mathrm{C} 3$ are similarly reduced by $20-30 \%$ when serum is treated with representative strains of Bacteroides or Proteus or $E$. coli. However, more analysis of the biological activity of each of the initial complement components is necessary to determine the precise locus affected by the bacteroides cells.

The cell concentration and $E$ h of the bacteroides culture appeared to be important 
in the impairment of opsonic activity of human serum. Bacteria harvested and washed in saline lost their biological activity, whereas resuspension in a medium with a low $E$ h such as saline containing $1 \%$ ascorbic acid or fresh culture medium (Robertson's cooked meat) restored their activity; these findings agree with those of Ingham et al. (1977). One or two batches of undiluted cooked-meat medium impaired opsonisation and phagocytosis of Proteus species per se but we were unable to determine the factor responsible; on dilution significant inhibitory activity was not detectable. At least $10^{5}$ bacteroides $/ \mathrm{ml}$ of human serum appeared to be necessary to cause significant impairment of opsonic activity.

Phagocytic uptake, measured over $45 \mathrm{~min}$ at $37^{\circ} \mathrm{C}$, of $P$. mirabilis by $\mathrm{PMNL}$ in the presence or absence of bacteroides cells showed significant differences that were further amplified when the killing rates were monitored over $5 \mathrm{~h}$. Although significant impairment of killing of Proteus was detectable even at $1 \mathrm{~h}$, the number of viable bacteroides did not decline over the 5-h period; this suggests that little or no phagocytosis of bacteroides occurred in these conditions.

We have shown that there is competition between different bacterial species for serum opsonins and subsequent phagocytic uptake and killing by PMNL. Whether such a process might also take place in vivo is open to question. Reznikov, Finlay-Jones and McDonald (1981) studied the clearance of $E$. coli from the peritoneal cavity of mice in the presence or absence of $B$. fragilis. Even at an anaerobe: coliform ratio of $80: 1$ there was no impairment of the rate of clearing of $E$. coli from the mouse peritoneum; both organisms were cleared at the same rate. It is unlikely that serum interactions with bacteria and subsequent phagocytosis by PMNL in vitro and in vivo are directly comparable. Accordingly, we are now extending these studies in an investigation of phagocytic activity within abscesses experimentally induced by the method of Joiner et al. (1980).

We are grateful for the skilled technical assistance of $\mathrm{Mr} \mathrm{R}$. McNaught.

\section{ADDENDUM}

Since this paper was submitted for publication Ingham et al. (1981) have reported that interaction of bacteroides cells with human serum can inhibit intracellular killing but not ingestion of $P$. mirabilis. The results of the present study indicate that ingestion and killing are inhibited. The reasons for this difference are not clear but may be related to the times of sampling used in the two studies. Ingham et al. (1981) studied phagocytosis after incubation for $5 \mathrm{~h}$ whereas a 45-min incubation period was used in the present study. A reduced rate of uptake of radiolabelled proteus cells was evident at this time, and the killing of Proteus spp. became impaired within 1-2 h.

\section{REFERENCES}

Duerden, B.I., Collee, J. G., Brown, R., Deacon, A. G. and Holbrook, W. P. 1980. A scheme for the identification of clinical isolates of gram-negative anaerobic bacilli by conventional bacteriological tests. Journal of Medical Microbiology, 13, 231-245.

Ingham, H. R., Sisson, P. R., Middleton, R. L., Narang, H. K., Codd, A. A. and Selkon, J. B. 1981. Phagocytosis and killing of bacteria in aerobic and anaerobic conditions. Journal of Medical Microbiology, 14, 391-399. 
Ingham, H. R., Sisson, P. R., Tharagonnet, D., Selkon, J. B. and Codd, A. A. 1977. Inhibition of phagocytosis in vitro by obligate anaerobes. Lancet, 2, 1252-1254.

Joiner, K. A., Gelfand, J. A., Onderdonk, A. B., Bartlett, J. G. and Gorbach, S. L. 1980. Host factors in the formation of abscesses. Journal of Infectious Diseases, 142, 40-49.

Miles, A. A., MisRa, S. S. AND IRWIN, J. O. 1938. The estimation of the bactericidal power of the blood. Journal of Hygiene, 38, 732-749.

Quie, P. G., Giebink, G. S. AND Peterson, P. K. 1981. Bacterial mechanisms for inhibition of ingestion by phagocytic cells. In Microbial perturbation of host defences, edited by $\mathrm{F}$. O'Grady and H. Smith, Academic Press, London, p. 121-141.

Reznikov, M., Finlay-Jones, J. J. AND MCDonald, P. J. 1981. Effect of Bacteriodes fragilis on the peritoneal clearance of Escherichia coli in mice. Infection and Immunity, 32, 398-399.

Tofte, R. W., Peterson, P. K., Schmeling, D., Bracke, J., Kim, Y. and Quie, P. G. 1980. Opsonization of four Bacteroides species: role of the classical complement pathway and immunoglobulin. Infection and Immunity, 26, 784-792.

Verhoef, J., Peterson, P. K. And Quie, P. G. 1977. Kinetics of staphylococcal opsonization, attachment, ingestion and killing by human polymorphonuclear leukocytes: a quantitative assay using $[3 \mathrm{H}]$ thymidine labelled bacteria. Journal of Immunological Methods, 14, 303-311. 